\title{
Economic Development and Intra-industry Trade in the Republic of Korea
}

\author{
Ranajoy Bhattacharyya \\ Calcutta University
}

\begin{abstract}
Vertical intra-industry trade dominates horizontal intra-industry trade in Korea. A time series analysis on both these types of intra-industry trade yields the following: (1) vertical intra industry trade was caused by the rapid economic development that the Korean economy experienced in the past thirty years and (2) horizontal intra-industry trade was more random in nature caused only by the aggregate volume of trade.
\end{abstract}

\section{- JEL Classifications: F12, F14}

- Key words: Vertical intra industry trade, Horizontal intra industry trade, Economic development, Causality

\section{Introduction}

The Republic of Korea has experienced rapid economic growth between the 1960s and the 1990s. At constant prices the Korean Gross Domestic Product (GDP) has roughly doubled between the early 1960s and the early 1990s. Its exponential growth rate between 1963 and 1991 is as high as 8.1 per cent per annum and the average annual growth rate of private consumption since the $1980 \mathrm{~s}$ has been a robust 6.5 per cent (World Development Report, 200-2001). In the same period its total trade volume has increased about 7.8 per cent per annum with imports and exports being consistently quite close to each other ${ }^{1}$, a phenomenon

\footnotetext{
*Corresponding address: Ranajoy Bhattacharyya, Department of Business Managements, Calcutta University, 1, Reformatory Street, Kolkata 70027, India, Tel: +91-33-2449-9418, Fax: +91-33-2241-3222, E-mail: branajoy@yahoo.com (C2005-Center for International Economics, Sejong Institution, All Rights Reserved.
} 
that is of special relevance to what follows. Also interesting is the overwhelming importance of manufacturing and machine and transport in total merchandise exports as well as imports. Thus not only GDP and total trade volume, but commodity trade both in and out of the country as well as in the same broad product category (SITC 7) has rapidly increased in this period ${ }^{2}$. How can we categorize this huge and rapidly rising trade? One way is to refer back to the traditional theories of international trade and try and test the explanatory power of those trade models. Several researchers have undertaken exercises such as these. It has been observed that the explanatory power of different traditional trade models in the Korean context has been moderate. While Kim et al (1983) (reported in Hong (1995) p-156) reports that about 57 per cent of the shifts in Korea's prodution and trade pattern from 1963 to 1982 could be explained by the HeckscherOhlin model, Hong (1987, table 6) finds that the capital labor ratio of Korean imports are about the same as Korean exports irrespective of whether all industries or only manufacturing industries are taken into account - an uncomfortable finding as far as the Heckscher-Ohlin theory is concerned. Kim et al (1983) also reports that the Ricardian model cannot account for the missing 43 per cent to any significant degree. These observations imply that the space for other theoretical structures apparently exists. The first objective of this paper is to use versions of the Grubel-lloyd (uncorrected) index to find out how far two (the vertical and the horizontal intra industry trade models) of the various kinds of intra industry trade (IIT) models possible can fill this void. It should be noted that while measuring IIT of the mixed variety for manufactured commodities in Korea Lee and Lee (1995) found that approximately half of Korean trade in this type of commodities is IIT. It also had a clear upward trend in their period of study (1977 to 1986). Thus the case for IIT has already been established for Korea. It should further be noted that according to Kim et al (1983) 'scale economies' performed better than the Ricardian model and could explain almost 20 per cent of total trade between 1963 and 1982. However it is now well known that scale economies are not necessary for IIT to take place. And IIT is not incompatible with the Heckscher- Ohlin theory

\footnotetext{
${ }^{1}$ Form the mid 1980s to the late 1980s Korean exports exceeded imports. The same phenomenon was noted in the late $1990 \mathrm{~s}$.

${ }^{2}$ Imports of SITC 7 products marginally dominated exports up to 1983 and were dominated by exports from 1984 to 2001 . In the mid 1980s the value of export and import was virtually identical. The two never really strayed much away from each other throughout this period
} 
(see, for example Jones et al (2000) and Bhagwati and Davis (2003)). Though this does not in any way disown the fact that IIT opens the door to a vast new array of theoretical models that can be used to explain the determinants of trade in a country ${ }^{3}$. Of the two IIT models studied here, the vertical IIT model is basically inter-industry in content to the extent that it overwhelmingly supports difference rather than similarity to prove its point. However it has never been formally subjected to the factor content approach ${ }^{4}$. On the other hand the horizontal IIT model in its popular form (see Krugman (1979)) argues in favour of similarity rather than difference in determining international trade ${ }^{5}$. In this sense therefore the first objective of the paper is to test the validity of two new models in the Korean context.

The rest of the paper empirically analyses the intra-industry part of total trade. Here the exact empirical task is difficult to pick. The force of Krugman's (1979) theoretical argument was such that much of the empirical work on IIT, it now seems, was a wasted effort. The focus was on testing his theory by using the Grubel-Lloyd index especially in the light of Krugman (1981). The tests generally failed to prove Krugman's case (see, for example, Leamer and Levinson (1995)) but it did as much damage to his argument as Leontief's finding did to the Heckscher-Ohlin argument. Subsequently the vertical IIT (VIIT) model (which should have been in vogue from the same year as Krugman's result (see, Gabszewicz and Thisse (1979)) came in and one of its first empirical versions showed (see, Greenaway, Hine and Milner (1995)) that even in a developed country $^{6}$ (UK, in this case) VIIT is what overwhelmingly happens in case of IIT $^{7}$. The empirical rationale of putting too much effort in trying to test the factually less important IIT using a general index (mostly the Grubel-Lloyd (uncorrected)) that

\footnotetext{
${ }^{3}$ This of course does not deny the fact that old models can do this as well. The old model-new trade and the new model-new trade controversy is not relevant for this paper.

${ }^{4}$ See, Gabszewiez and Thisse (1979), Shaked and Sutton (1989) and several others

${ }^{5}$ There were many debates in the 1990s regarding the tenability of this statement (see, for example Davis (1995)). The debate died down by the end of the 1990s and interest of economists shifted to newer areas, the statement still survives.

${ }^{6}$ Krugman's argument is more relevant for developed countries than for underdeveloped countries to the extent that it invokes Dixit and Sitglitz (1979).

${ }^{7}$ For empirical work on vertical intra-industry trade see: Bhattacharyya (2002), Aturupane et al (1999), Balance et al (1992), .
} 
does not recognize this difference can be attributed to the novelty of Krugman's argument and the late realization of Gabszewicz and Thisse's argument in trade theory. In the VIIT model trade occurs mainly through the novelty of the demand side, the supply side being typically primitive though essential (a difference in marginal cost of producing quality being all that is required to generate the main result). It was thus natural for it to be marginally relevant in the theoretical context (trade theory is all about the supply side, the demand side are at most graduate exercises). As a result it never got the minute empirical attention that its horizontal part got. Viewed from the supply side the VIIT model is basically a North-South model. In the class of models in this category that is briefly discussed below the basic empirical task from the supply side is to find out whether the marginal cost of producing quality is significantly different in the trading partners. Assuming that there is a link between the wage paid to the worker and quality achieved (in the absence of wage bargaining (see Gabszewicz and Turrini (2000)) a comparison of skilled wages in the North and the South can propose an empirical hypothesis to test the above result. However this hypothesis is apparent, even casually, and it has been indirectly and comprehensively addressed by the now huge literature on falling unskilled to skilled wage rate in developed countries (see, for example Krugman (2000) for a theoretical discussion on the issue). In this paper therefore we will look at VIIT from the demand side. Using a simple oligopolistic model of VIIT we will argue that there is a positive link between VIIT and the level of economic development of a country. We will also use Krugman (1981) to show that the 2 country horizontal IIT (HIIT) model has no clear results as far as the relationship between economic development and HIIT is concerned. Accordingly our empirical hypothesis will be that there is a causal link between economic development of a country and VIIT, for HIIT the link is expected to be weak or absent. We will then use the Korean IIT data to test these propositions.

The rest of the paper is arranged as follows: In the next section we take a comprehensive look at IIT, VIIT and HIIT for Korea. In section III we determine the theoretical results that motivate our empirical analysis. Section IV presents the empirical results and the last section concludes the paper.

\section{ITT in Korea}

Table 1 reports Korea's multilateral IIT between 1963 and $1995^{8}$ at the SITC 3 digit level ${ }^{9}$ calculated by using the Grubel-Lloyd (uncorrected) (1975) index: 
Table 1. Korean IIT (1963-1995) ${ }^{1}$.

\begin{tabular}{cccc}
\hline YEAR & IIT & YEAR & IIT \\
\hline 1963 & 0.092 & 1980 & 0.295 \\
1964 & 0.058 & 1981 & 0.36 \\
1965 & 0.131 & 1982 & 0.329 \\
1966 & 0.105 & 1983 & 0.374 \\
1967 & 0.079 & 1984 & 0.402 \\
1968 & 0.109 & 1985 & 0.426 \\
1969 & 0.156 & 1986 & 0.331 \\
1970 & 0.152 & 1987 & 0.352 \\
1971 & 0.221 & 1988 & 0.359 \\
1972 & 0.303 & 1989 & 0.306 \\
1973 & 0.351 & 1990 & 0.347 \\
1974 & 0.361 & 1991 & 0.393 \\
1975 & 0.330 & 1992 & 0.433 \\
1976 & 0.354 & 1993 & 0.435 \\
1977 & 0.321 & 1994 & 0.452 \\
1978 & 0.305 & 1995 & 0.453 \\
1979 & 0.287 & & \\
\hline
\end{tabular}

Note: 1. IIT calculated by using the Grubel-Lloyd (1975) index: IIT $=1-\left[\Sigma\left|X_{i}-M_{i}\right| \Sigma\left(X_{i}+M_{i}\right)\right]$ where $X_{i}$ and $M_{i}$ are export and import of the ith industry. See Vona (1991) for a detailed discussion of the index. Source: Calculated from International Trade Statistic Yearbook, UN,(various issues).

$G L(U)=1-\left[\Sigma\left|X_{i}-M_{i}\right|\left\langle\Sigma\left(X_{i}+M_{i}\right)\right]\right.$, where $X_{i}$ and $M_{i}$ are export and import of the ith industry. Mean multilateral IIT over the entire period is 30 per cent ${ }^{10}$ with a rising trend but a falling growth rate over the successive decades ${ }^{11}$. By 1995 about half of Korea's trade was intra-industry in character.

Table 2 disaggregates this IIT of the mixed variety into its vertical and horizontal components. We use the unit value criterion for this classification (see Greenaway

\footnotetext{
${ }^{8}$ The years were basically chosen on the basis of the availability of data. However, to the extent that Korea's first five year plan started in 1962 and the financial crisis hit Korea in 1998, the data covers an important period of rapid and continuous progress.

${ }^{9}$ SITC 5 to SITC 8.

${ }^{10}$ The website KITA.org gives Korea's bilateral and multilateral export import data for SITC classifications. Till March, 2003 the data available was only from 1991. It has therefore not been used here. However a recalculation to check the consistency of the estimates here showed that IIT calculated from that data has an upward bias. One reason may be that whereas the International Trade Statistics Yearbook does not report export (import) data for industries having less than 3 percent of total exports (imports) (which means that zero values were automatically assigned to them for this calculation), the KITA website reports all industries. A more detailed analysis of the causes have not been undertaken.

${ }^{11}$ Growrth rate (least squares): 1960s: 9 per cent, 1970s: 4 per cent, 1980 to 1995: 2 per cent, aggregate: 5 per cent.
} 
Table 2. Breakup of Korea's Intra-Industry Trade into Horizontal and Vertical Components (3 Digit SITC)

\begin{tabular}{|c|c|c|c|c|}
\hline Year & IITHOR $^{1}$ & NIITHOR $^{2}$ & IITVER $^{3}$ & NIITVER $^{4}$ \\
\hline 1963 & 0 & 0 & 0.473 & 0.076 \\
\hline 1964 & 0 & 0 & 0.373 & 0.057 \\
\hline 1965 & 0 & 0 & 0.638 & 0.131 \\
\hline 1966 & 0.016 & 0.0002 & 0.293 & 0.067 \\
\hline 1967 & 0.068 & 0.003 & 0.099 & 0.021 \\
\hline 1968 & 0.795 & 0.051 & 0.253 & 0.1 \\
\hline 1969 & 0.496 & 0.059 & 0.328 & 0.131 \\
\hline 1970 & 0.604 & 0.04 & 0.329 & 0.133 \\
\hline 1971 & 0.294 & 0.008 & 0.31 & 0.056 \\
\hline 1972 & 0.996 & 0.032 & 0.384 & 0.261 \\
\hline 1973 & 0.876 & 0.051 & 0.442 & 0.289 \\
\hline 1974 & 0.355 & 0.093 & 0.556 & 0.254 \\
\hline 1975 & 0.502 & 0.059 & 0.453 & 0.133 \\
\hline 1976 & 0.563 & 0.092 & 0.485 & 0.105 \\
\hline 1977 & 0.562 & 0.032 & 0.55 & 0.172 \\
\hline 1978 & 0.438 & 0.075 & 0.495 & 0.163 \\
\hline 1979 & 0.796 & 0.091 & 0.616 & 0.157 \\
\hline 1980 & 0.568 & 0.06 & 0.597 & 0.114 \\
\hline 1981 & 0.877 & 0.021 & 0.634 & 0.18 \\
\hline 1982 & 0.924 & 0.041 & 0.626 & 0.164 \\
\hline 1983 & 0.971 & 0.06 & 0.618 & 0.149 \\
\hline 1984 & 0.777 & 0.018 & 0.674 & 0.289 \\
\hline 1985 & 0.505 & 0.037 & 0.739 & 0.329 \\
\hline 1986 & 0.418 & 0.035 & 0.708 & 0.221 \\
\hline 1987 & 0.535 & 0.033 & 0.567 & 0.173 \\
\hline 1988 & 0.623 & 0.002 & 0.871 & 0.014 \\
\hline 1989 & 0 & 0 & 0.819 & 0.017 \\
\hline 1990 & 0.562 & 0.153 & 0.602 & 0.082 \\
\hline 1991 & 0.598 & 0.049 & 0.643 & 0.07 \\
\hline 1992 & 0.535 & 0.121 & 0.695 & 0.09 \\
\hline 1993 & 0 & 0 & 0.891 & 0.08 \\
\hline 1994 & 0.727 & 0.005 & 0.65 & 0.07 \\
\hline 1995 & 0.699 & 0.053 & 0.605 & 0.389 \\
\hline Mean & 0.5 & 0.04 & 0.55 & 0.14 \\
\hline s.d. ${ }^{5}$ & 0.31 & 0.04 & 0.18 & 0.09 \\
\hline
\end{tabular}

Notes:1. The uncorrected Grubel-Loyed index for horizontal intra-industry trade defined at the 15 percent level. 2. Adjusted Grubel-Lloyd index for horizontal intra-industry trade at the 15 percent level (see text for definition). 3. The Grubel-Loyed index for vertical intra-industry trade defined at the 15 percent level 4. The new index for vertical intra-industry trade at the 15 percent level (see text for definition). (in each case ' 15 per cent level' means that if the export and import unit values differed more than $15 \%$ the industry is considered as a vertical trade industry. See Greenaway, Hine andd Milner (1995).)5. Standard deviation. 6. Correlation between IITHOR and NIITHOR=.42, IITVER and NIITVER $=.24$ 
et al (1995)): SITC 3-digit level industries whose unit values of export and import differ more than \pm 15 per cent are defined as industries which take part in vertical trade, the rest take part in horizontal trade. It is important to note that classifying IIT into VIIT and HIIT in this fashion leads to a serious problem. Usually classifying SITC 3 digit industries into ones where vertical and horizontal trade occurs, leaves an unequal number of industries in each category (in Korea's case, the number of industries with vertical trade far exceeded that with horizontal trade). For the category which has a small number of industries, if these industries happen to have a large proportion of trade as IIT, then the aggregate IIT reported by the Grubel-Lloyd index will be large irrespective of whether the there industries account for a tiny amount of total trade or a large amount of total trade. To adjust for the scale effect the index has therefore been modified as ${ }^{12}$ :

$$
\begin{aligned}
& N_{I I T_{V E R}}=\left[\frac{M_{V E R}+X_{V E R}}{M_{T O T}+X_{T O T}}\right] \times G L(U)_{V E R} \\
& N_{I I T_{H O R}}=\left[\frac{M_{H O R}+X_{H O R}}{M_{T O T}+X_{T O T}}\right] \times G L(U)_{H O R}
\end{aligned}
$$

Where M stands for import and X for export while VER, HOR and TOT stand for vertical, horizontal and total trade. Obviously: $\mathrm{M}_{\mathrm{VER}}+\mathrm{M}_{\mathrm{HOR}}=\mathrm{M}_{\mathrm{TOT}}$ and similarly for export. Note that if we represent the value of the multilateral Grubel-Lloyd index as GL(U) then: $\mathrm{NIIT}_{\mathrm{VER}}+\mathrm{NIIT}_{\mathrm{HOR}}=\mathrm{GL}(\mathrm{U})$ even though GL(U) $)_{\mathrm{VER}}+\mathrm{GL}(\mathrm{U})_{\mathrm{HOR}} \neq$ $\mathrm{GL}(\mathrm{U})^{13}$. Thus the adjustment is a necessary step if one were to find out how multilateral IIT is exactly distributed over its vertical and horizontal components. This of course begs the question as to how adding NIIT $\mathrm{VER}_{\text {and }}$ NIIT $_{\mathrm{HOR}}$ in table 2 do not give the exact figure of multilateral IIT in table 1. There are two reasons for it: first, to calculate unit value indices all industries for which either import or export is zero had to be eliminated (as there was no way of comparing their prices),

\footnotetext{
${ }^{12}$ See also Bhattacharyya (2002).

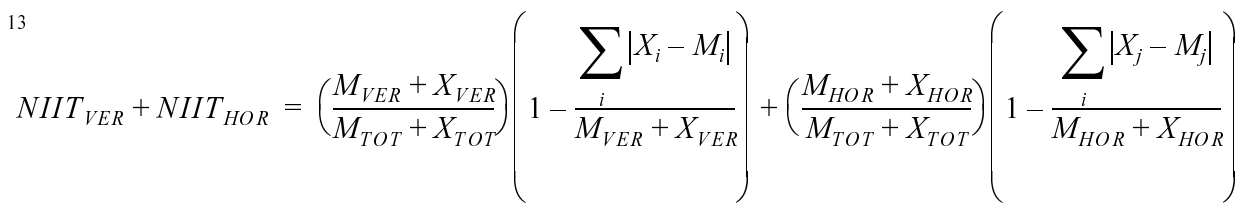

where there are $\mathrm{i}$ horizontal trade industries and $\mathrm{j}$ vertical trade industries. This, on simple manipulation yields the Grubel-Lloyd index. 
second, figures for quantities were not available in all industries for which values were reported so they had also to be excluded. Thus the two tables are not comparable to the extent that they should have been.

Table 2 reports the values of both the adjusted index defined above and the unadjusted Grubel-Lloyd index. Irrespective of the index used in table 2 we find that VIIT has clearly dominated HIIT for Korea. However note that there is a low correlation between the indices - an indication of the fact that the two indices are fundamentally different. As mentioned above the difference is the following: whereas the Grubel-Lloyd index simply calculates the proportion of IIT in total trade exclusively within the particular category (say, horizontal), the adjusted index takes into account the fact that the proportion of total trade accounted for by that category may be small. Smaller is the proportion of total trade accounted for by, say, horizontal trade (trade occurring in industries whose export and import unit values are within $15 \%$ of each other) smaller will be the value of the new index. Since the mean value of the new adjusted index falls more drastically for HIIT compared to VIIT, it is obvious that HIIT is limited to industries where the relative volume of total trade (export plus import) is very low. This is also reflected in the fact that the standard deviation across years falls significantly after adjustment. However since the mean of the unadjusted indices are close to each other $(.50$ and .54 ), the proportion of IIT in total trade in these relatively unimportant ${ }^{14}$ industries is almost as high as in case of VIIT industries. Both these observations mean that the adjusted index is a more reliable proxy for classifying IIT than the unadjusted index. We will therefore use this index for the empirical analysis below.

\section{Economic Development and IIT: The Theoretical Link}

The theoretical link between HIIT and economic development is by no means unambiguous. In the traditional $2 \times 2$ model of Horizontal IIT (Krugman (1981)) the link is between endowment similarity and the proportion of IIT implying by it that all other relationships are contingent upon it. The proportion of IIT will increase with economic development if this also brings the two countries closer in some sense (for example, endowments or technology or by induction incomes). However economists have traditionally tested hypotheses regarding the link between

\footnotetext{
${ }^{14}$ Unimportant in the trade sense only: total export and import in these industries are small compared to total export and import in all industries.
} 
economic development and IIT using this model (as early examples see, Havrylyschyn, and Civan (1983) and Bergstrand (1983)). The argument being that as economies of scale and incomes increase IIT should increase. However as Helpman, and Krugman (1985) (chapter 9) admit the relationship even in the multi-country case is contingent upon rather unrealistic assumptions. Thus in spite of efforts, the relationship is yet to be cut and dried in its theoretical form. In the appendix we use a simplified version of Krugman (1981) to derive the following proposition between economic development and HIIT:

Observation 1: Assuming that economic development somehow brings the trading countries closer to each other HIIT increases

As far as VIIT is concerned the link, especially from the demand side is much more obvious and unconditional. In the literature the demand side has been modeled both from the point of view of aggregate income and its distribution (see Gullstrand (2003)). In the version of the VIIT model we consider in the appendix people are uniformly arranged according to their income (we thus digress from distributional effects). This implies that one way economic development can be considered is by adding people at the top of the income spectrum. Now assume that there are two qualities of a product produced by two producers living in two different countries (a case of international duopoly). The high quality product has a higher price and is hence consumed by the richer people (having an income above a cut-off point) in both countries. Poorer people consume the poor quality product in both countries. Since there is demand for both products in both countries, IIT occurs. Let us now assume that people are added to the upper end of the income spectrum. This immediately increases the demand for the high quality product and its price. The increase in price forces the people who could just about afford the product to shift to the low quality product increasing its demand as well as price. Assuming a stable duopoly equilibrium it is shown in the appendix that the loss in consumers due to increase in price is smaller than the original gain that triggers off the price rise. Thus, for the VIIT case:

\section{Observation2: Economic development increases VIIT unambiguously}

It is thus obvious that VIIT is expected to have a stronger relationship with economic development than HIIT. We will test this proposition using the Korean 
data below. We will assume that a 'strong' comparative static relationship like the one discussed above can be tested as a long run cointegrating relationship between the variables over time. Thus from the theoretical exercise we clearly expect cointegration between VIIT and variables that proxy for economic development. But to the extent that there is no guarantee that Korea's economic development has brought it closer (in any sense) to all its trading partners (we are dealing with multilateral HIIT in this paper), we do not expect HIIT to cointegrate with the same variables. The result regarding the mixed IIT index is reported as a matter of course. Since it does not have any theoretical backup, the expected result is basically unknown. However note that Havrylyschyn, and Civan (1983) got a positive result with this kind of mixed IIT. Since variables that cointegrate usually have direct or reverse causality, we test for causality for the cases where cointegration exists. Here the question that is posed is: does economic development cause VIIT or HIIT. The above theoretical observations clearly implies that once more we expect an answer in the affirmative in the VIIT case and a negative in the HIIT case. However there is no theoretical ground of expecting reverse causality (from VIIT or HIIT to economic development).

\section{Results}

In this section we will test the following (null) hypotheses with the multilateral trade data of Korea between 1963 and 1995: economic development is cointegrated with and causes both HIIT and VIIT ${ }^{15}$. As mentioned above the two (comparative static) observations in the previous section point to the fact that while VIIT has a positive link with economic development irrespective of the trading partner (and therefore in the multilateral sense) the trading partner plays an important role in determining the link between HIIT and economic development. In particular it is important to get a clear answer to the following question: does economic development in Korea bring the trading partner closer to Korea in some economic sense (such as endowments or technology)? If the answer is yes then HIIT will increase with economic development otherwise it will decrease with

\footnotetext{
${ }^{15}$ Leamer (1995), while commenting on the link between exports and GNP cautions us by saying “(s)tudies of 'Granger causal orderings' of exports and GNP are not identifying causal directions but are only asking the question whether movements in exports tend to precede or follow movements in GNP".
} 
economic development. To the extent that the multilateral trade data contains export and import from both types of countries (those that come closer and those that move further away as Korea becomes economically developed) the link between economic development and HIIT is expected to be fuzzy (absent or weak) as the positive and negative effects of economic development on VIIT cancel out. Our theoretical exercise thus unambiguously suggests that economic development should cointegrate with and has a strong causal link with VIIT and may not cointegrate with HIIT.

For the regression analysis we take a more generalized look at "economic development" than the one suggested by the theoretical exercise (see table 3 ). As table 3 (column 3 ) explains each variable is a proxy for an important determinant of economic development. While GDP and CON capture it from the demand side, MANU, CAP and DFI capture it from the supply side. The variable total trade volume (TOT) is included to capture the effect of rising volumes of trade on IIT. The problem of taking so many proxies of the same general variable (economic development) is that they are expected to be correlated to each other leading to a problem of multicolinearity in the vector autogegressive process. The correlations

Table 3. Variables and their proxies ${ }^{1}$.

\begin{tabular}{|c|c|c|c|}
\hline Variable & Full name of variable & Proxy for & Source \\
\hline GDP & Gross Domestic Product & $\begin{array}{c}\text { General Indicator of } \\
\text { economic development }\end{array}$ & $\begin{array}{c}\text { National Accounts Statistics, } \\
\text { U.N. (Various issues) }\end{array}$ \\
\hline MANU & $\begin{array}{l}\text { Manufacturing as a } \\
\text { proportion of GDP }\end{array}$ & Industrial performance & $\begin{array}{c}\text { National Accounts Statistics, } \\
\text { U.N. (Various issues) }{ }^{2}\end{array}$ \\
\hline CAP & $\begin{array}{c}\text { Gross Capital Formation as a } \\
\text { proportion of expenditure on } \\
\text { GDP (capital output ratio) }\end{array}$ & Structure of industries & $\begin{array}{c}\text { National Accounts Statistics, } \\
\text { U.N. (Various issues) }{ }^{2}\end{array}$ \\
\hline $\mathrm{CON}$ & $\begin{array}{l}\text { Final Consumption Expendi- } \\
\text { ture of Resident Households }\end{array}$ & Purchasing Power & $\begin{array}{c}\text { National Accounts Statistics, } \\
\text { U.N. (Various issues) }{ }^{2}\end{array}$ \\
\hline TOT & $\begin{array}{l}\text { Exports }+ \text { Imports of goods } \\
\text { and services }\end{array}$ & Total trade volume & $\begin{array}{c}\text { National Accounts Statistics, } \\
\text { U.N. (Various issues) }{ }^{2}\end{array}$ \\
\hline DFI & $\begin{array}{c}\text { Flow of direct investment } \\
\text { capital in Korea }\end{array}$ & Foreign investment & $\begin{array}{l}\text { International Financial Sta- } \\
\text { tistics Yearbook } 1997 \text { issue }\end{array}$ \\
\hline TAR & $\begin{array}{c}\text { Custom's duty as a proportion } \\
\text { of import value }\end{array}$ & Trade barriers & $\begin{array}{c}\text { Government Finance Statis- } \\
\text { tics, IMF (1980,1989, } 1997 \\
\text { issues) }\end{array}$ \\
\hline
\end{tabular}

Notes: 1. All variables are at constant prices. All the variables have a positive expected sign except TAR. 2. The 1971 issue was used for data regarding 1963-1973. The 1981 issue was used for data regarding 1971-1979. The 1991 issue was used for data regarding 1980-1991. 3. Different price bases were adjusted using simple interpolation. 
between the independent variables are presented in table 4. All these correlation coefficients are fairly high in magnitude. To test whether this observed degree of association is statistically significant or not, let us assume that if the population correlation coefficient $\delta>0.5$ between any pair of independent variables then that would be taken as a conclusive evidence of muticollinearity. To test Ho: $\delta=0.5$ we have applied the $\mathrm{Z}$ - transformation technique where the test statistic is defined as:

$$
\delta=(\mathrm{n}-3)^{1 / 2}(\mathrm{Z}-\delta) \sim \mathrm{N}(0,1)
$$

with $Z=1 / 2 \ln [(1+r) /(1-r)]$ and $\delta=1 / 2 \ln [(1+\delta) /(1-\delta)]$ where $\mathrm{r}$ and $\delta$ are the sample and the population correlation coefficients respectively.

Most of these $\delta$ - value are significant at less than 1 per cent level (see table 4) and all of them are significant at 5 per cent level. So, a conjecture of muticollinearity is strongly supported. In what follows we therefore take the explanatory variables one at a time.

Table 5 and 6 present the unit root tests for the variables. Though it is not usual to report the unit root tests in such detail, it should be noted that the results are highly sensitive to the level at which they are deduced to be stationary. Further, usually there is a contradiction regarding the order of integration between different tests (with/without trend in the data generating process or augmentations in the

Table 4. Correlation Matrix of Independent Variables (levels) ${ }^{1}$.

\begin{tabular}{ccccccc}
\hline MANU & CAP & TAR & DFI & TOT & CON & \\
\hline GDP & 0.99 & 0.98 & 0.97 & 0.89 & 0.98 & 0.99 \\
& $(35.7)$ & $(25.1)$ & $(20.3)$ & $(12.9)$ & $(25.1)$ & $(35.7)$ \\
MANU & & 0.98 & 0.98 & 0.92 & 0.99 & 0.99 \\
& & $(25.1)$ & $(25.1)$ & $(14.0)$ & $(35.7)$ & $(25.1)$ \\
CAP & & & 0.94 & 0.91 & 0.97 & 0.98 \\
& & & $(14.0)$ & $(11.2)$ & $(20.3)$ & $(25.1)$ \\
TAR & & & & 0.87 & 0.98 & 0.97 \\
& & & & $(8.2)$ & $(25.1)$ & $(15.5)$ \\
DFI & & & & & 0.91 & 0.88 \\
& & & & & $(11.2)$ & $(8.6)$ \\
TOT & & & & & & 0.98 \\
& & & & & & $(17.5)$ \\
\hline
\end{tabular}

Notes: 1. Figures in brackets are $\delta$ values (see text for definition). 
Table 5. Determining lag(s), trend and drift in the data generating process.

\begin{tabular}{lcccc}
\hline \multicolumn{1}{c}{ Variable } & LM $^{1}$ & $\Phi_{1}{ }^{2,6}$ & $\xi_{1}{ }^{3,6}$ & Conclusion $^{4}$ \\
\hline IIT & 1.81 & .82 & 2.14 & NL,NT,ND \\
VIIT & $5.40^{* 5}$ & .45 & .10 & $1 \mathrm{~L}, \mathrm{NT}, \mathrm{ND}$ \\
& $\left(1.17^{7}\right)$ & & & \\
HIIT & $2.97^{* 5}$ & & & \\
& $\left(4.01^{* 7}\right)$ & .70 & 1.15 & $2 \mathrm{~L}, \mathrm{NT}, \mathrm{ND}$ \\
GDP & $\left(.72^{8}\right)$ & & & \\
MANU & .09 & $8.90^{*}$ & .49 & NL,T,ND \\
CAP & .32 & $9.98^{*}$ & 1.20 & NL,T,ND \\
TAR & .21 & $4.53^{*}$ & .77 & NL,T,ND \\
DFI & $.4 .82^{* 5}$ & $9.99^{*}$ & 1.12 & $1 \mathrm{~L}, \mathrm{~T}, \mathrm{ND}$ \\
TOT & $(.61)$ & $4.53^{*}$ & 1.23 & NL,T,ND \\
CON & 2.63 & $13.35^{*}$ & $4.51^{*}$ & NL,T,D \\
\hline
\end{tabular}

Notes: 1. In $\Delta y_{t}=\alpha+\beta t+\gamma Y_{t-1}+\varepsilon_{t}$ Lagrange multiplier test for residual serial correlation. 2. F statistic for Imposing zero restrictions on $\mathrm{t} 3$. F statistic for imposing zero restriction on $\alpha 4$. $\mathrm{L}=\mathrm{lag}, \mathrm{T}=$ trend, $\mathrm{D}=\mathrm{drift}$ (an ' $\mathrm{N}$ ' in front of these letters implies absence of the relevant factor). 5. LM statistic with no lag (number in front of ' $\mathrm{L}$ ' implies the number of lags required to eliminate autocorrelation in: $\Delta \mathrm{y}_{\mathrm{t}}=\alpha+\beta \mathrm{t}+\gamma \mathrm{Y}_{\mathrm{t}-1}$. 6. '*' implies statistically significant at 5 per cent 7. LM statistic with one period lag 8. LM statistic with two period lag

Table 6. Unit root test for the variables.

\begin{tabular}{ccccc}
\hline Variable & Relevant test statistic $^{1}$ & Calculated value of test ststistic $^{2}$ & Concluion $^{3}$ \\
\hline IIT & & Level & 1st Diff. & \\
VIIT & $\mathrm{DF}_{\mathrm{NT}}$ & -1.39 & $-4.96^{*}$ & $\mathrm{I}(1)$ \\
HIIT & $\mathrm{ADF}_{\mathrm{NT}}$ & -2.82 & $-4.77^{*}$ & $\mathrm{I}(1)$ \\
GDP & $\mathrm{ADF}_{\mathrm{NT}}$ & -2.98 & $-5.35^{*}$ & $\mathrm{I}(1)$ \\
MANU & $\mathrm{DF}_{\mathrm{T}}$ & +2.07 & -3.45 & $\mathrm{I}(2)$ \\
CAP & $\mathrm{DF}_{\mathrm{T}}$ & +.69 & $-3.19^{*}$ & $4^{*}$ \\
TAR & $\mathrm{DF}_{\mathrm{T}}$ & +2.54 & -2.82 & $\mathrm{I}(1)$ \\
DFI & $\mathrm{ADF}_{\mathrm{T}}$ & -1.41 & $-6.05^{*}$ & $\mathrm{I}(2)$ \\
TOT & $\mathrm{DF}_{\mathrm{T}}$ & -.63 & $-5.36^{*}$ & $\mathrm{I}(1)$ \\
CON & $\mathrm{DF}_{\mathrm{T}}$ & 1.16 & -3.85 & $\mathrm{I}(1)$ \\
\hline
\end{tabular}

Notes: 1. (A)DF = (Augmented) Dickey-Fuller statistic, $\mathrm{T}$ in the subscript implies with trend and WT in the subscript implies without trend in the data generating process. 2. ' $*$ ' implies the null hypothesis of the existence of unit root is rejected at the 95 per cent level. 3. I(i) integrated of order i. 4. Second difference results (as the relevant variables are non-stationary at the first difference).

Dickey-Fuller equation). We have thus chosen to report the exact criteria we have used for determining the order of integration ${ }^{16}$. The criteria that we have adopted is first to check whether there is a drift and trend component in the data generating 
process and whether lags are required to eliminate serial correlation(table 5). Accordingly we have used the Dickey Fuller test with or without augmentation and time trend to determine whether we have unit roots in the data generating

Table 7. Test for co-integration with IIT(HIIT)[VIIT] $]^{1,2}$

\begin{tabular}{|c|c|c|c|c|c|c|}
\hline Variable & $\begin{array}{l}\text { Trace }^{4,5} \\
\left(\mathrm{H}_{0}:\lceil=0)\right.\end{array}$ & $\begin{array}{c}\text { Trace }^{4,5} \\
\left(\mathrm{H}_{0}:\lceil\leq 1)\right.\end{array}$ & $\begin{array}{c}\text { Max. eigen } \\
\text { value }^{3,5} \\
\left(\mathrm{H}_{0}:\lceil=0)\right.\end{array}$ & $\begin{array}{c}\text { Max. eigen } \\
\text { value }^{3,5} \\
\left(\mathrm{H}_{0}:\lceil\leq 1)\right.\end{array}$ & $\begin{array}{c}\text { co-integrating } \\
\text { vector (No.) }\end{array}$ & $\begin{array}{c}\text { Normalized } \\
\text { co-integrating vector }\end{array}$ \\
\hline$\triangle \mathrm{GDP}$ & $\begin{array}{c}1.38 \\
(1.13) \\
{[.32]}\end{array}$ & $\begin{array}{c}1.38 \\
(1.13) \\
{[.32]}\end{array}$ & $\begin{array}{c}3.47 \\
\left(9.77^{* *}\right) \\
{\left[16.89^{*}\right]}\end{array}$ & $\begin{array}{c}4.85 \\
(10.90) \\
{\left[17.22^{*}\right]}\end{array}$ & $\begin{array}{c}0 \\
(0) \\
{[1]}\end{array}$ & {$[.00007]$} \\
\hline MANU & $\begin{array}{c}12.61 \\
\left(17.52^{* *}\right) \\
{\left[37.86^{*}\right]} \\
\end{array}$ & $\begin{array}{c}2.43 \\
(3.69) \\
{\left[11.53^{*}\right]} \\
\end{array}$ & $\begin{array}{c}10.17 \\
\left(13.82^{* *}\right) \\
{\left[26.33^{* *}\right]}\end{array}$ & $\begin{array}{c}2.43 \\
(3.69) \\
{\left[11.53^{*}\right]}\end{array}$ & $\begin{array}{c}0 \\
(0) \\
(2)\end{array}$ & $\begin{array}{l}{[.00005]} \\
{[.00006]}\end{array}$ \\
\hline$\triangle \mathrm{CAP}$ & $\begin{array}{c}5.59 \\
(11.20) \\
{\left[17.67^{*}\right]}\end{array}$ & $\begin{array}{c}1.51 \\
(2.25) \\
{[1.79]}\end{array}$ & $\begin{array}{c}4.08 \\
(8.94) \\
{\left[15.87^{*}\right]}\end{array}$ & $\begin{array}{c}1.50 \\
(2.25) \\
{[1.79]}\end{array}$ & $\begin{array}{c}0 \\
(0) \\
{[1]}\end{array}$ & {$[-.0002]$} \\
\hline TAR & $\begin{array}{c}11.42 \\
(9.72) \\
{\left[25.49^{*}\right]}\end{array}$ & $\begin{array}{c}.003 \\
(2.06) \\
{[4.18]}\end{array}$ & $\begin{array}{c}11.41 \\
(7.76) \\
{\left[21.31^{*}\right]}\end{array}$ & $\begin{array}{c}.003 \\
(2.06) \\
{[4.18]} \\
\end{array}$ & $\begin{array}{c}0 \\
(0) \\
{[1]}\end{array}$ & [.0005] \\
\hline DFI & $\begin{array}{c}6.34 \\
(15.10) \\
{\left[30.89^{*}\right]} \\
\end{array}$ & $\begin{array}{c}1.46 \\
(1.65) \\
{\left[7.60^{*}\right]} \\
\end{array}$ & $\begin{array}{c}4.87 \\
\left(13.45^{* *}\right) \\
{\left[22.98^{*}\right]} \\
\end{array}$ & $\begin{array}{c}1.46 \\
(1.65) \\
{\left[7.60^{*}\right]} \\
\end{array}$ & $\begin{array}{c}0 \\
(0) \\
{[2]}\end{array}$ & $\begin{array}{l}{[.0007]} \\
{[.0006]}\end{array}$ \\
\hline TOT & $\begin{array}{l}17.78^{* *} \\
\left(26.54^{*}\right) \\
{\left[40.13^{*}\right]} \\
\end{array}$ & $\begin{array}{c}3.16 \\
\left(7.05^{* *}\right) \\
{\left[13.40^{*}\right]} \\
\end{array}$ & $\begin{array}{l}14.00^{* *} \\
\left(19.49^{*}\right) \\
{\left[26.73^{*}\right]}\end{array}$ & $\begin{array}{c}3.16 \\
\left(7.05^{* *}\right) \\
{\left[13.40^{*}\right]}\end{array}$ & $\begin{array}{c}0 \\
(1) \\
{[2]}\end{array}$ & $\begin{array}{l}.00009) \\
{[.00006]} \\
{[.00007]} \\
\end{array}$ \\
\hline $\mathrm{CON}$ & $\begin{array}{c}3.35 \\
(9.84) \\
{\left[20.07^{*}\right]}\end{array}$ & $\begin{array}{l}.001 \\
(.06) \\
{[.08]}\end{array}$ & $\begin{array}{c}3.35 \\
(9.78) \\
{[19.99 *]}\end{array}$ & $\begin{array}{l}.001 \\
(.06) \\
{[.08]}\end{array}$ & $\begin{array}{c}0 \\
(0) \\
{[1]}\end{array}$ & {$[-.0004]$} \\
\hline
\end{tabular}

Notes: 1. All values outside brackets are for IIT. All values within first (second) brackets are for HIIT (VIIT). 2. Only those values which are significant at the 95 per cent are considered as significant. 3 . Critical values for the maximal eigenvalue test for $\mathrm{H}_{0}:\left\lceil=0 \& \mathrm{H}_{1}\lceil=1\right.$ is 14.06 at 95 per cent $\mathrm{CV}$ and 12.07 at 90 per cent $\mathrm{CV}$ and $\mathrm{H}_{0}:\left\lceil\leq 1\right.$ and $\mathrm{H}_{1}:\lceil=\mathrm{z}$ is 3.76 at $95 \% \mathrm{CV}$ and 2.68 at $90 \% \mathrm{CV}$. 4. Critical values for the trace test for $\mathrm{H}_{0}:\left\lceil=0\right.$ and $\mathrm{H}_{1}:\left\lceil\geq 1\right.$ is 15.4 at 95 per cent $\mathrm{CV}$ and 13.3 at $90 \% \mathrm{CV}$ and $\mathrm{H}_{0}:\lceil\leq 1$ and $\mathrm{H}_{1}:\lceil=2$ is 3.76 at 95 per cent $C V$ and 2.68 at 90 per cent CV.5. * implies Null hypothesis rejected at 95 per cent $\mathrm{CV}, * *$ implies that the null hypothesis rejected at 90 per cent $\mathrm{CV}$.

\footnotetext{
${ }^{16}$ Note that in table 6 the order of the ADF test is assumed to be the number of lags required in the relevant equation (that is $\Delta \mathrm{Y}_{\mathrm{t}}=\alpha+\beta \mathrm{t}+\gamma \mathrm{Y}_{\mathrm{t}-1}+\varepsilon_{\mathrm{t}}$ ) to make $\varepsilon_{\mathrm{t}}$ white noise. For this reason the calculated value of the lagrange multiplier statistic in the above equation is reported in table 5
} 
process ${ }^{17}$. It can be seen from tables 5 and 6 that all the variables except CAP and GDP are I(1). CAP and GDP are I(2).

Table 7 reports the cointegration results for all the three kinds of IIT. It is clear from the table that only VIIT has a strongly positive long run relationship with economic development. The results thus exactly confirm the theoretical predictions made in the previous section. The only variable that cointegrates with HIIT is total trade volume. So HIIT in Korea can be considered as a symptom of rising trade volumes rather than economic development in general. A mere link to trade volumes may or may not translate to any meaningful relationship with economic development. We therefore conclude from table 7 that there is no clear link between HIIT and economic development for Korea between 1963 and 1995. The result is in direct contrast to several observations made in the early days of empirical IIT literature (and hardly revisited later) regarding the positive link between mixed IIT and economic development with theoretical results derived exclusively on the basis of HIIT (see, for example, Havrylyschyn and Civan,

Table 8. Error correlation coefficients $\left(\lambda_{1}, \phi_{1}, \eta_{1}\right)$ for Granger causality $X_{t}=$ VIIT.

\begin{tabular}{ccccccc}
\hline \multirow{2}{*}{ Variable } & \multicolumn{3}{c}{ From $\mathrm{Y}_{\mathrm{t}}$ to $\mathrm{X}_{\mathrm{t}}$} & \multicolumn{3}{c}{ From $\mathrm{X}_{\mathrm{t}}$ to $\mathrm{Y}_{\mathrm{t}}$} \\
\cline { 2 - 7 } & $\lambda_{1}{ }^{1}$ & $\phi_{1}{ }^{2}$ & $\eta_{1}{ }^{3}$ & $\lambda_{1}$ & $\phi_{1}$ & $\eta_{1}$ \\
\hline $\mathrm{Y}_{\mathrm{t}}=\Delta$ CAP & -.14 & -1.9 & -2.5 & -.35 & -.18 & -.03 \\
& $(-1.5)^{4}$ & $\left(-1.8^{* *}\right)$ & $\left(-2.0^{*}\right)$ & $(-1.4)$ & $(-.53)$ & $(-.08)$ \\
$\mathrm{Y}_{\mathrm{t}}=$ TOT & -.17 & -.20 & -.26 & .06 & .07 & -.004 \\
& $\left(-1.7^{* *}\right)$ & $(-1.6)$ & $\left(-1.7^{* *}\right)$ & $(1.5)$ & $\left(1.7^{* *}\right)$ & $(-.12)$ \\
$\mathrm{Y}_{\mathrm{t}}=\mathrm{GDP}$ & -.22 & -.25 & $-.37^{*}$ & .06 & .06 & .10 \\
& $\left(-1.8^{* *}\right)$ & $\left(-1.8^{* *}\right)$ & $\left(-2.2^{*}\right)$ & $\left(1.8^{* *}\right)$ & $(1.5)$ & $\left(2.6^{*}\right)$ \\
$\mathrm{Y}_{\mathrm{t}}=$ MANU & -.10 & -.20 & -.27 & .03 & .04 & .04 \\
& $(-1.6)$ & $(-1.6)$ & $\left(-1.7^{* *}\right)$ & $(1.0)$ & $(1.0)$ & $(1.0)$ \\
$\mathrm{Y}_{\mathrm{t}}=\Delta$ CON & -.18 & -.25 & -.30 & .15 & .44 & .45 \\
& $\left(-1.7^{* *}\right)$ & $\left(-2.1^{*}\right)$ & $\left(-2.2^{*}\right)$ & $(.59)$ & $\left(1.7^{* *}\right)$ & $(1.2)$ \\
$\mathrm{Y}_{\mathrm{t}}=$ TAR & -.17 & -.20 & -.24 & -.03 & .002 & -.06 \\
& $\left(-1.7^{* *}\right)$ & $(-1.5)$ & $(-1.5)$ & $(-.52)$ & $(.02)$ & $(-.91)$ \\
$\mathrm{Y}_{\mathrm{t}}=$ TOT & -.71 & -.62 & -.59 & .09 & .13 & .07 \\
$\mathrm{X}_{\mathrm{t}}=$ HIIT & $\left(-2.8^{*}\right)$ & $\left(-2.1^{*}\right)$ & $\left(-1.8^{* *}\right)$ & $\left(3.0^{*}\right)$ & $\left(3.3^{*}\right)$ & $(1.2)$ \\
\hline
\end{tabular}

Notes: 1 . One period lag (see section IV for the interpretation of the $\lambda \mathrm{s}$ ). 2 . Two period lag. 3. Three period lag. 4. Figures in brackets are t- values. “*” implies accepted at 5 per cent level. “**” implies accepted at 10 per cent level.

\footnotetext{
${ }^{17}$ We have followed Rao (1990) for the unit root and causality tests and have used Microfit 3.0 (see Peseran and Pesaran (1990).
} 
(1983) and Bergstrand (1983)).

Turning to VIIT and to table 8 we see that economic development generally causes VIIT and is never caused by it. Interestingly, the causality from total trade volume (TOT) to VIIT is absent at the 95 per cent level. VIIT therefore cannot be classified as a symptom of rising trade volumes, which HIIT can be (the last row of table 8 shows that trade volume causes VIIT). VIIT is therefore clearly caused by determinants of economic development other than trade volumes and exclusively trade volumes cause HIIT. Given the above discussion it seems obvious that the multilateral data studied here suggests a link between economic development and VIIT but not HIIT.

\section{Conclusion}

In Korea VIIT dominates HIIT and has been caused by the rapid economic development that the nation has experienced in the past three decades. HIIT on the other hand is not caused by it. It is has been simply caused by rising trade volumes which has increased the interaction between producers and consumers in foreign countries. The paper thus strongly argues in favor of VIIT and singles it out as a possible area of further research as far as IIT is concerned.

Received 1 July 2004, Accepted 26 December 2004

\section{References}

Aturupane, C., S. Djankov, and B. Hoekman (1999) "Horizontal and Vertical Intra-Industry Trade between Eastern Europe and the European Union", Weltwirtschaftliches Archiv, Vol. 135.

Ballance, R., H. Forstner, and W. C. Sawyer (1992) "An Empirical Examination of the Role of Vertical Product Differentiation in North-South Trade", Weltwirtschaftliches Archiv, vol. 128.

Bergstrand, J.H (1983) "Measurement and Determinants of Intra-Industry Trade" in PKM Tharakan (Ed) Intra-Industry Trade: Empirical and Methodological Aspects. Amsterdam.

Bhagwati, J. and Davis, D.R. (2003) "Intra Industry Trade: Issues and Theory", in James Melvin, James Moore and Ray Reizman (-eds) Trade Welfare and Econometrics: Essays in Honour of John. S. Chipman, Routledge, New York.

Bhattacharyya, R, (2000) "Economic Development in the Basic model of Intra-Industry trade", Indian Economic Journal, Vol. 48. No. 4.

— (2002) "Vertical and Horizontal Intra-Industry trade in some Asian and Latin American 
Less developed Countries". Journal of Economic Integration, vol. 17.

Bughin, J. (1995), Unions and strategic managerial incentives, Economics Letters 47, 95100.

Davis, R.D. (1995) "Intra-Industry Trade: A Heckscher-Ohlin-Ricardo Approach", Journal of International Economics, Vol. 39.

Dickey, D.A., Jansen, D.W. and Thornton, D.L. (1994) "A Premier on Cointegration with an Application to Money and Income". in Cointegration for the Applied Economist (Ed.) B.Bhaskara Rao. St. Martin's Press. New York.

Dowrick, S., 1989, Union-oligopoly bargaining, Economic Journal vol. 99.

Engle, R.F and Yoo, B.S. (1987) "Forecasting and Testing in Cointegrated Systems". Journal of Econometrics. Vol. 35.

Gabszewicz, J., and Thisse. J. F., 1979, Price competition, quality and income disparities, Journal of Economic Theory, vol. 20.

-, and Turrini, A., 2000, Workers' skills, product quality and industry equilibrium, International Journal of Industrial Organization, vol. 18.

Globerman, S. and Deane, J.W. (1990) "Recent Trends in Intra Industry Trade and Their Implications for Future Trade Liberalization". Weltwirtschaftliches Archiv, Vol.126.

Greenaway, D., Hine, R. and Milner, C. (1994) "Country Specific Factors and The Pattern of Horizontal and Verical Intra-Industry Trade in the UK", Weltwirtschaftliches Archiv, Vol. 130.

- (1995) "Vertical and Horizontal Intra-Industry Trade: A Cross Industry Analysis for the United Kingdom", Economic Journal, Vol. 105.

Greenaway, D., C. Milner., and R. Elliott (1999) "UK Intra-Industry Trade with EU North and South", Oxford Bulletin of Economics and Statistics, vol. 61.

Grubel, H. and Lloyd, P.J. (1975) Intra Industry Trade: The Theory and Measurement of International trade in differentiated Products. Macmillan. London.

Gullstrand, J. (2003) "Demand Patterns and Vertical Intra-Industry Trade With Special Reference to North-South Trade", Lund University, mimeo.

Hamilton, J.D.(1994) Time Series Analysis.Princeton University Press. Princeton. New Jersey.

Havrylyschyn, O. and Civan, E. (1983) "Intra Industry trade and The Stages of Development: A Regression Analysis of Industrial And Developing countries." in P.K. Tharakan (Ed) Intra Industry Trade: Empirical and Methodological Aspects, Amsterdam.

Helpman, E. (1987) "Imperfect Competition and International Trade: Evidence From Fourteen Industrialized Countries", Journal of Japanese and International Economics,vol.1.

Hong, W. (1995) Trade and Growth : A Korean Perspective, Seoul: Kurada International $\mathrm{Hu}$, X., and Y. Ma (1999) "International Intra-Industry Trade of China", Weltwirtschaftliches Archiv, vol.135.

Internatinal Trade Statistics Yearbook, Volumes 1 and 2, 1989 to 1995. UN.

Johansen, S. and Juselius, K.(1990) "Maximum Likelihood Estimation and Inference on Cointegration with Applications to the demand for money". Oxford Bulletin of 
Economics and Statistics,.. Vol.

Jones,R. Marjit,S. and Beladi,H (1998) “Three Faces of Factor Intersities", University of Rochester, (mimeo).

Kraft, K., 1998, The Codetermined firm in oligopoly, Economics Letters, vol. 61.

Krugman, P.R. (1979) "Increasing Returns, Monopolistic Competition and International Trade". Journal of International Economics. Vol.9.

- (1981) "Intra Industry Specialization and Gains from Trade". Journal of Political Economy. Vol. 89.

- (2000) "Technology, trade and factor prices", Journal of International Economics, vol. 50.

Leamer, E.E. (1995) "Testing Trade Theory" in David Greenaway and L. Alan Winters (ed) Surveys in International Trade, Blackwell, Oxford.

— and Levinson, J. (1995) "International Trade Theory: The Evidence" in G.M. Grossman and K. Rogoff (Ed.) Handbook of International Economics. Vol.3.

Lee, H.H. and Y.Y. Lee (1995) "Intra-Industry Trade in Manufactures: The case of Korea", Weltwirtschaftliches Archiv, vol.

Pesaran, M.H. and Pesaran, B. (1990) Microfit 3.0, An Interactive Econometric Software Package. User Mannual. Oxford University Press. New York

Motta, M., 1993 "Endogenous Quality Choice: Price vs Quantity Competition", The journal of Industrial Economics, Vol. Xli.

Naylor, R. (1999) "Union Wage Strategies and International Trade", Economic Journal, January.

Scmitt, N. and Yu, Z. (2001) "Economies of Scale and the Volume of Intra-Industry Trade", GEP Research Paper No. 2001/08.

Shaked, A. and Sutton, J. (1989) "Natural Ologopolies and International trade". in H.Kierzkowski (Ed.) Monopolistic Competition and International Trade. Clarendon Press. Oxford.

Thrakan, P.K.M (1986) "Intra Industry Trade of Benelux With The Developing World" Weltwirtschaftliches Archiv. Vol. 122.

Tirole, J., 1988, The Theory of Industrial Organization, The MIT Press.

Torstensson, J. (1996) "Determinants of Intra Industry Trade: A Sensitivity Analysis". Oxford Bulletin of Economics and Statistics. Vol.58.

- (1991) "Quality Differentiation and Factor Proportions in International Trade: An Empirical Test of the Swedish Case", Weltwirtschaftliches Archiv vol. 127.

Vona, S. (1991) "On The Measurement of Intra Industry Trade: some Future Thoughts" Weltwirtschaftiches Archiv. 


\section{Appendix}

\section{Link between HIIT and economic development in Krugman (1981)}

Let there be two goods $X$ and $Z, X$ is a horizontally differentiated manufactured good and $\mathrm{Z}$ is a homogeneous primary good such as food. There are two factors of production labour $(L)$ and capital $(K)$. $Z$ uses only labour while $X$ uses both labour and capital. There are two countries, home and foreign. Following Krugman (1979, 1981) we assume that a typical variety seeking consumer has the following utility function:

$$
U=\left[\sum X_{i}^{\theta}\right]^{1 / \theta}+Z
$$

Let us further assume that $X$ requires one unit of labour as variable cost and $\gamma$ units of capital as fixed cost for its production. An unit of $Z$ requires $\beta$ units of labour only. We also assume that price for $X$ is set by the usual mark-up-over $\operatorname{cost}^{18}$ principle and $Z$ is the numeraire good. Thus:

$$
\begin{gathered}
C x=w x+\gamma r \\
C z=w \beta Z \\
P x=w / \gamma \\
P z=1=\beta w
\end{gathered}
$$

where $\mathrm{Ci}$ and $\mathrm{Pi}$ are the cost and price of the ith industry respectively and $\mathrm{w}$ and $\mathrm{r}$ are the returns to labour and capital respectively.

Let consumers $\mathrm{j}$ spend $\alpha$ proportion of his income $\left(Y_{j}\right)$ on $X$ and the rest on food. And let this be true for all consumers. Then:

$$
\alpha y=n P_{x} x
$$

where $y=\sum y_{i}=w L+r K$ is the economy's total income.

Finally we hàve the zero profit condition and the full employment conditions:

$$
\begin{gathered}
(P x-w) x=\gamma r \\
L=n x+\beta Z \\
K=m
\end{gathered}
$$

We assume that the same amount of labour is used in both countries in both industries but different amounts of capital are used to produce $x$. Denoting all

\footnotetext{
${ }^{18}$ The utility function gives us a demand function for $X$ which has elasticity $1 /(1-\theta)$. Since marginal cost for $\mathrm{X}$ equals $\mathrm{w}$ therefore we get the equation by using the well known relationship between marginal revenue, price and the elasticity of demand.
} 
foreign magnitudes by ' $*$ ' we have:

$$
\begin{aligned}
& P_{x}=\frac{w}{\theta}, P_{x}^{*}=\frac{w^{*}}{\theta} \\
& 1=P_{z}=\beta w, 1=P_{z}^{*}=\beta w^{*} \\
& \left(P_{w}-w\right) x=\gamma r,\left(P_{w}^{*}-w^{*}\right) x^{*}=\gamma^{*} r^{*} \\
& L=n x+\beta z, L^{*}=n^{*} x^{*}+\beta z^{*} \\
& K=\gamma n, K^{*}=\gamma^{*} n^{*} \\
& \alpha\left(y+y^{*}\right)=n P_{x} x+n^{*} P_{x}^{*} x^{*}
\end{aligned}
$$

Where the last equation is the changed commodity market condition.

Note that in our model, the capital abundant country, is a net exporter of manufactured goods, has a higher per capita income and produces more varieties ${ }^{19}$. These facts will be useful in interpreting the results below.

In terms of the model just developed the value of the Grubel-Lloyd index can be determined as follows. We know,

$$
\begin{gathered}
\alpha y=n^{*} C_{H}{ }^{*}+n C_{H} \\
\alpha y^{*}=n C_{F}+n^{*} C_{F}{ }^{*}
\end{gathered}
$$

Where $C_{H}$ and $C_{H}{ }^{*}$ are the consumption of each variety of $X$ and $X^{*}$ by the home consumers. Similarly $C_{F}$ and $C_{F}{ }^{*}$ are the consumption of $X$ and $X^{*}$ by foreign consumers. Now,

and,

$$
C_{H}{ }^{*}=\alpha y /\left(n+n^{*}\right)
$$

$$
C_{F}=\alpha y * /\left(n+n^{*}\right)
$$

Import and export of $\mathrm{x}$ by the home country is:

$$
M_{x}=n^{*} C_{H}{ }^{* 20} \text { and } X_{x}=n C_{F}
$$

where $M_{x}$ and $X_{x}$ are import and export of $X$.

Putting these values in the index we have:

$$
I_{g l(u)}=1-\frac{\sum\left|1-\frac{n^{\prime} y}{n^{*} / y^{*}}\right|}{\sum\left|1+\frac{n^{\prime} y}{n^{*} / y^{*}}\right|}
$$

\footnotetext{
${ }^{19}$ For example, let us assume in the above model that $\mathrm{L}=\mathrm{L}^{*}$ but $\mathrm{K}<\mathrm{K}^{*}$. Clearly form the definitions of $\mathrm{y}$ and $y^{*}, y^{*}>y$, that is $\left(y^{*} / L^{*}\right)>(y / L)$. Also $n^{*}>n$.

${ }^{20}$ Helpman and Krugman (1983) choose to write Mx as $2 \mathrm{ypn}^{*} \mathrm{x} * \mathrm{y}+\mathrm{y} *$ ).
} 
Since, $y=w L+r K$ and $Y^{*}=w L^{*}+r K^{*}$. Therefore:

$I I T=1-\left\{L / K-L^{*} / K^{*}\right\} /\left\{L / K+L^{*} / K^{*}+r\right\}$

where $r=2 \alpha \theta\left(L+L^{*}\right) /(1-\alpha)\left(K+K^{*}\right)$. Note that if $L / K=L^{*} / K^{*}$ then $I_{G L(U)}=1$ and that as the trading partners come close endowment wise IIT increase.

Let us now turn to the issue of economic development. The suggestion that we will make here is that economic development will increase IIT provided that it brings the countries closer to each other endowment wise, otherwise it reduces IIT. We first consider a situation where an increase in national income (economic development) does not affect the number of varieties produced (in our model this can be done by increasing $L$ or $L^{* 21}$ ). In such a situation, an increase in national income of the home country will effect IIT of the home country positively iff it is a net exporter of industrial products. To prove this let us note that the Grubel-Lloyd index, which measures the proportion of IIT in total trade, can be rewritten as:

$$
I_{G L(U)}=I I T=1-2 \frac{\sum \min \left(X_{i}, M_{i}\right)}{\sum\left(X_{i}, M_{i}\right)}
$$

in terms of the model, assuming that $X x>M x$, we have:

$$
I I T=2 M_{X} /\left(M_{X}+X_{X}\right)=2 n^{*} C_{H}^{*} /\left(n^{*} C^{*}{ }_{H}+n C_{F}\right)^{22}=2 n^{*} y /\left(n * y+n y^{*}\right)
$$

Differentiating IIT w.r.t. y we have:

$$
\frac{\delta I I T}{\delta Y}=\frac{1}{\Delta}\left[2 n^{*} \frac{\delta C_{H}^{*}}{\delta y}\left(n^{*} C_{H}^{*}+n C_{F}\right)-2 n^{*} C_{H}^{*}\left(n \frac{\delta C_{H}^{*}}{\delta y}+n \frac{\delta C_{F}}{\delta y}\right)\right]
$$

From (2) and the values of $C_{H}{ }^{*}$ and $C_{F}$ this implies that

$\delta I I T / \delta y=(1 / \Delta)$ n $C_{F}\left[2 n^{*} \alpha /\left(n+n^{*}\right)\right]>0$. However if $X_{X}<M_{X}$ then, $\delta I I T / \delta y=-(1 / \Delta)$ $n C_{F}\left[2 n^{*} \alpha /\left(n+n^{*}\right)\right]<0$.

Thus we have shown that the effect on IIT for an increase in national income of the home country depends on whether the country is a net importer or a net exporter of the manufactured good. The intuition behind the result is that higher is $y$ higher is $M x$ so that IIT will increase only if $M x$ is smaller and catches up export as a result of its increase. We have already noted that in our model lower is the number of varieties produced by a country lower is its export (or equivalently the

\footnotetext{
${ }^{21} \mathrm{As} \mathrm{L}$ increases ( $\mathrm{K}$ being held constant) demand for capital increases and from (3.A.2) $\mathrm{r}$ increases but $\mathrm{w}$ remains unchanged (as the capital abundant manufacturing sector bids away the extra labour) thus $y$ increases (this is of course a feature of this fixed coefficients model).

${ }^{22}$ Putting the values of $C_{H}^{*}$ and $C_{F}$ we can rewrite IIT as: $I I T=2 n^{*} y /\left(n^{*} y+n y^{*}\right)$.
} 
capital rich country is the net exporter of the manufactured product). The result thus shows that if the number of varieties produced at home is lower than the number of varieties produced abroad (the foreign country is capital rich) and if economic development at home does not affect the number of varieties produced then demand for foreign goods will increase further with economic development without a corresponding increase in export and IIT will fall. This is clearly in line with the direct relationship between similarity of endowment and IIT. The increase in $\mathrm{L}$ in the home country (which is labour rich in this case) draws the countries further from each other in terms of endowments, and IIT falls. The result can of course be generalised to the case where variety also changes.

\section{Link between VIIT and economic development}

There are two firms situated in two countries indexed by $L$ and $H$ and engaged in a game of quality choice followed by price competition for a product that is vertically differentiated. Let the lower quality of the product be denoted as $\mathrm{q}_{\mathrm{L}}$ (produced in country $L$ ) and the associated quantity demanded as $X_{L}$. Similarly, the higher quality of the product is denoted as $\mathrm{q}_{\mathrm{H}}$ (produced in country $\mathrm{H}$ ) and its associated demand is $X_{H}$. A typical consumer's preference is: $U_{i}=q_{i}-(1 / \gamma) p_{i}$, $i=L, H$ where the price of the $\mathrm{i}$-th quality product is $p_{i}$ and $\gamma$ is a parameter that can be interpreted as the inverse of the marginal rate of substitution between income and quality (see Tirole, 1988, p.96). ${ }^{23}$ There is a continuum of consumers in both countries who are uniformly distributed over an interval $\left(\gamma_{-}, \bar{\gamma}\right) ; 0<\gamma<1$. As is the case with such models, consumers will be segregated in terms of their purchase of the variety in each country. There is a critical reservation value $\left(\gamma^{\mathrm{C}}\right.$, say) above which all consumers consume the high quality variety and below which consumers consume the low quality variety: $\gamma^{\mathrm{C}}=\left(\mathrm{p}_{\mathrm{H}}-\mathrm{p}_{\mathrm{L}}\right) /\left(\mathrm{q}_{\mathrm{H}}-\mathrm{q}_{\mathrm{L}}\right)$. Further assume that the entire market is served ${ }^{24}$. Thus $\mathrm{X}_{\mathrm{L}}=2\left(\bar{\gamma}-\gamma^{\mathrm{C}}\right)$ and $\mathrm{X}_{\mathrm{H}}=2\left(\gamma^{\mathrm{C}}-\underline{\gamma}\right)$.

\footnotetext{
${ }^{23} \gamma$ is a reservation value for the consumer depending on his income. In particular, $\gamma$ can be interpreted as the inverse of the marginal rate of substitution between income and quality: $\gamma=1 / \mathrm{U}^{\prime}(\mathrm{I})$ where $\mathrm{I}$ is the level of income. We assume $\mathrm{U}$ to be concave so that $\gamma$ rises with the level of income. Consumers can be thought of being uniformly distributed between income levels $\left(\underline{I}_{2} \overline{\mathrm{I}}\right)$. Assuming that the reservation value of the person with the highest ( $\overline{\mathrm{I}})$ and lowest (I) Incomes are $\bar{\gamma}$ and $\underline{\gamma}$ respectively, the distribution can be stated in terms of the interval $\left(\mathcal{\gamma}_{2} \bar{\gamma}\right)$.

${ }^{24}$ This assumption simplifies our demand functions. The demand functions for the two varieties are:

$X_{H}=\int_{\gamma}^{\bar{\gamma}} d \gamma=\bar{\gamma}-\frac{p_{H}-p_{L}}{q_{H}-q_{L}} \quad X_{L}=\int_{\underline{\gamma}}^{\gamma^{c}} d \gamma=\frac{p_{H}-p_{L}}{q_{1}-q_{2}}-\underline{\gamma}$
} 
Having chosen different qualities in the first stage, firms engage in price competition in the second stage. For simplicity, we assume that the cost of production is fixed. It is straightforward to see that the equilibrium prices and quantities $\operatorname{are}^{25}$ :

$$
p_{H}=\frac{1}{3}(2 \bar{\gamma}-\underline{\gamma}) \Delta q, p_{L}=\frac{1}{3}(\bar{\gamma}-2 \underline{\gamma}) \Delta q, X_{L}=\frac{2}{3}(\bar{\gamma}-2 \underline{\gamma}), X_{H}=\frac{2}{3}(2 \bar{\gamma}-\underline{\gamma}) \text { resulting }
$$

in profits $\pi_{H}=m \Delta q-W_{H}, \pi_{L}=m \Delta q-W_{L}$ where $m=\frac{1}{9}\left(2+\underline{\gamma}^{2}\right), n=\frac{1}{9}(1-\underline{\gamma})^{2}$ and $\Delta q=q_{H^{-}} q_{L}$.

Note that both the firms would prefer maximal differentiation as that would increase prices and profits. To what extent the differentiation can be enlarged will depend on the costs of choosing quality. Here we may be reminded that this game has generically two asymmetric Nash equilibria with firms implicitly coordinating on their asymmetric quality choice. If they end up with identical quality, their profits will be zero, a result of co-ordination failure. The type of trade that emerges from this setup is VIIT in the product $X . L$ exports $X_{L}$ to the low-income people in $\mathrm{H}$ and $\mathrm{H}$ exports $X_{H}$ to the high income people in L. The total amount of VIIT is the volume of trade in $X$, that is, $1 / 2\left(X_{H}+X_{L}\right)$.

Let us suppose now that a new consumer has been added at the upper end of the income (or $\gamma$ ) spectrum. It can be seen from the above that both $X_{H}$ and $X_{L}$ increase increasing VIIT unequivocally. The reason is simple: as an individual is added to the upper end of the income spectrum, the demand for the high quality good immediately increases increasing its price. This increases the demand for low quality products as well (as $\gamma^{\complement}$ increase) increasing its price as well as production.

\footnotetext{
${ }^{25}$ See, for example Motta(1993) for a full characterization of this stage.
} 